\title{
Capitation based funding of general practice is not fit for purpose
}

\author{
David Shepherd GP and Leicester City CCG Board Member
}

Saffron Health, Leicester LE2 6UL, UK

I disagree with Majeed's call for activity based funding for primary care, which would be a backwards step, ditching an important driver of cost effectiveness. ${ }^{1}$

He rightly says that this would be more expensive, but there are more fundamental problems. The current capitation based funding is not fit for purpose, for two reasons-the level of funding is inadequate, as many have pointed out, and the Carr-Hill formula is flawed.

In Leicester we have shown substantial variation in disease prevalence between neighbouring practices, with corresponding workload implications, despite identical geographies. Current funding formulas miss this, as they don't use patient level data. The historically unequal core funding per head has been largely equalised across Leicester by raising all to a common baseline. However, case mix adjustment using adjusted clinical groups (ACG) ${ }^{2}$ with further adjustment for variation in coding completeness, shows at least a twofold variation in average practice ACG cell prevalence, which is associated with cost and healthcare demand.

In other words, practices are not funded in proportion to the clinical demand they face. This constitutes a waste of NHS resources and partly explains why some practices seem more stressed than others, despite similar funding per head.

Modifying capitation based funding to an adequately resourced, case mix adjusted method, based on patient level data is essential and possible. This retains the advantages of capitation funding by not rewarding pointless activity and by giving practices a fair and direct incentive to find more efficient ways of working, something desperately needed given funding pressures. It also tackles flaws in the current formula, which is unable to capture the detailed variation in clinical demand needed for a fair system. We need to adjust for variation in multimorbidity between practices.

Competing interests: I am a practising GP and partner in a UK general practice and CCG board member.

Full response at: http://www.bmj.com/content/358/bmj.j3191/rr.

Majeed A. Shortage of general practitioners in the NHS. BMJ 2017;358:j3191. doi:10. 1136/bmj.j3191 pmid:28694250

2 Johns Hopkins ACG System. https://www.hopkinsacg.org/

Published by the BMJ Publishing Group Limited. For permission to use (where not already granted under a licence) please go to http://group.bmj.com/group/rights-licensing/ permissions 